19. Bachet J, Termignon J-L, Goudot B, Dreyfus G, Piquois A, Brodaty D, et al. Aortic root replacement with a composite graft. Factors influencing immediate and long-term results. Eur J Cardiothorac Surg. 1996;10:207-13.

20. Gott VL, Gillinov AM, Pyeritz RE, Cameron DE, Reitz BA, Greene PS, et al. Aortic root replacement. Risk factor analysis of a seventeen-year experience with 270 patients. J Thorac Cardiovasc Surg. 1995;109:536-45.

21. Pacini D, Ranocchi F, Angeli E, Settepani F, Pagliaro M, MartinSuarez S, et al. Aortic root replacement with composite valve graft. Ann Thorac Surg. 2003;76:90-8.

22. Dossche KM, Schepens MA, Morshuis WJ, Brutel de la Rivière A, Knaepen PJ, Vermeulen FEE. A 23-year experience with composite valve graft replacement of the aortic root. Ann Thorac Surg. 1999;67: 1070-7.

23. Hilgenberg AD, Akins CW, Logan DL, Vlahakes GJ, Buckley MJ, Madsen JC, et al. Composite aortic root replacement with direct coronary artery implantation. Ann Thorac Surg. 1996;62:1090-5.

24. Byrne JG, Karavas AN, Leacche M, Unic D, Rawn JD, Couper GS, et al. Impact of concomitant coronary artery bypass grafting on hospital survival after aortic root replacement. Ann Thorac Surg. 2005;79:511-6.
25. Kirsch M, Ginat M, Lecerf L, Houel R, Loisance D. Aortic wall alterations after use of gelatin-resorcinol-formalin glue. Ann Thorac Surg. 2002;73:642-4.

26. Bingley JA, Gardner MAH, Stafford EG, Mau TK, Pohlner PG, Tam RKW, et al. Late complications of tissue glues in aortic surgery. Ann Thorac Surg. 2000;69:1764-8.

27. Cabrol C, Gandjbakhch I, Cham B. Anévrysmes de l'aorte ascendante. Remplacement total avec réimplantation des artères coronaires. Nouv Presse Med. 1978;7:363-5.

28. Piehler JM, Pluth JR. Replacement of the ascending aorta and aortic valve with a composite graft in patients with nondisplaced coronary ostia. Ann Thorac Surg. 1982;33:406-9.

29. Mills NL, Morgenstern DA, Gaudiani VA, Ordoyne F. "Legs" technique for management of widely separated coronary arteries during ascending aortic repair. Ann Thorac Surg. 1996;61:869-74.

30. Najafi H. Aneurysm of cystic medionecrotic aortic root. J Thorac Cardiovasc Surg. 1973;66:71-4.

31. Zubiate P, Kay JH. Surgical treatment of aneurysm of the ascending aorta with aortic insufficiency and marked displacement of coronary ostia. J Thorac Cardiovasc Surg. 1976;71:415-21.

\title{
ON THE MOVE?
}

\section{Send us your new address at least six weeks ahead}

Don't miss a single issue of the journal! To ensure prompt service when you change your address, please photocopy and complete the form below.

Please send your change of address notification at least six weeks before your move to ensure continued service. We regret we cannot guarantee replacement of issues missed due to late notification.

JOURNAL TITLE:

Fill in the title of the journal here.

OLD ADDRESS:

Affix the address label from a recent issue of the journal here.
NEW ADDRESS:

Clearly print your new address here.

Name

Address

City/State/ZIP

\section{COPY AND MAIL THIS FORM TO:}

Elsevier Inc.

Subscription Customer Service

6277 Sea Harbor Dr

Orlando, FL 32887
OR FAX TO:

407-363-9661

OR E-mail:

elspcs@elsevier.com
OR PHONE:

800-654-2452

Outside the U.S., call

407-345-4000 